\title{
PERLINDUNGAN HUKUM BAGI PARA PIHAK DALAM E-COMMERCE SEBAGAI AKIBAT DARI GLOBALISASI EKONOMI
}

\author{
Lathifah Hanim \\ Dosen Fakultas Hukum UNISSULA \\ I.hanim00@yahoo.com
}

\begin{abstract}
Globalization's impact on the development of technological advances free trade between countries. through international trade spawned free trade rules and more focus on the development of a free market, quickly in a life without limits. The realization of the consequences of free trade globalization is the emergence of the phenomenon of Electronic Commerce. The research method used is normative juridical. legal research literature is legal research conducted by examining the library materials or secondary data. The results obtained that legal protection for parties in E-Commerce as a result of economic globalization include the two sides are in agreement and outside the Agreement, as well as E-Commerce Transactions settings in Act No. 11 of 2008 can be described as the need for the existence of an Institution Certification Reliability to certify to the party who will conduct electronic transactions (Article 10); Setting the implementation of the Electronic Transactions (Article 17 Paragraph (3)); Regulation on Electronic Contract for Electronic Transactions (Article 18 Paragraph (1)); Dispute Resolution on Electronic Transactions (Article 18, Paragraph (3)); Electronic system as a system implementation Electronic Transactions (Article 19); Regulation on Electronic Agents as intermediaries in Electronic Transactions (Article 21 and 22).
\end{abstract}

Keyword : Protection of Law, E-Commerce, Economic Globalization.

\begin{abstract}
Abstrak
Globalisasi dunia berdampak pada berkembangnya kemajuan teknologi perdagangan bebas antar negara. melalui perdagangan internasional melahirkan aturan perdagangan bebas serta lebih fokus pada pengembangan pasar bebas, cepat dalam suatu kehidupan tanpa batas. Wujud dari akibat Globalisasi perdagangan bebas adalah munculnya fenomena Electronic Commerce. Metode Penelitian yang digunakan adalah yuridis normatif. penelitian hukum kepustakaan adalah penelitian hukum yang dilakukan dengan cara meneliti bahan pustaka atau data sekunder. Hasil penelitian yang diperoleh bahwa perlindungan hukum bagi para pihak dalam E-Commerce sebagai akibat dari globalisasi ekonomi mencakup dua sisi yaitu dalam Perjanjian dan diluar Perjanjian, serta Pengaturan Transaksi E-Commerce dalam Undang-Undang No 11 Tahun 2008 dapat dijabarkan seperti diperlukannya keberadaan suatu Lembaga Sertifikasi Keandalan untuk melakukan sertifikasi terhadap pihak yang akan melakukan transaksi elektronik (Pasal 10); Pengaturan pelaksanaan Transaksi Elektronik (Pasal 17 Ayat (3));Pengaturan mengenai Kontrak Elektronik terhadap Transaksi Elektronik (Pasal 18Ayat (1)); Penyelesaian Sengketa atas Transaksi Elektronik (Pasal 18 Ayat (3)); Sistem Elektronik sebagai sistem pelaksanaan Transaksi Elektronik (Pasal 19); Pengaturan mengenai Agen Elektronik sebagai perantara dalam melakukan Transaksi Elektronik (Pasal 21 dan 22).
\end{abstract}

Kata Kunci : Perlindungan Hukum, E-Commerce, Globalisasi Ekonomi.

\section{A. PENDAHULUAN}

Gobalisasi menggambarkan proses percepatan interaksi yang luas dalam bidang politik, teknologi, ekonomi, sosial dan budaya. Globalisasi merupakan istilah yang digunakan untuk menggambarkan multi lapis dan multi dimensi proses dan fenomena hidup serta pelaksanaan yang terjadi. ${ }^{1}$

1 Fauzie Yusuf Hasibuan, 2010, Keseimbangan Dan Keterbukaan: Dalam Kontrak Anjak Piutang di Indonesia, Jakarta, Fauzie \& Partners, hIm.1. 
Globalisasi dimaksudkan sebagai proses pengintregasian perekonomian negara-negara ke arah masyarakat ekonomi dunia yang saling terkait, saling tergantung, dan saling pengaruhmempengaruhi. Globalisasi ekonomi diperlihatkan oleh saling tergantung dan bahkan pengintegrasian produksi. $^{2}$ Globalisasi menimbulkan akibat yang sangat besar terhadap aspek kehidupan bermasyarakat terutama aspek hukum, globalisasi hukum terjadi dalam arti substansi berbagaiundang-undang dan kontrak-kontrak menyebar melewati batas-batas ruang lingkup suatu negara semakin menjadi samar, namun dari hal demikian juga tampak bahwa hukum antar negara-negara di dunia menjadi semakin terintegrasi.

Percepatan proses globalisasi dalam dua dekade terakhir ini secara fundamental telah mengubah struktur dan pola hubungan perdagangan dan keuangan internasional. Hal ini menjadi fenomena penting sekaligus merupakan suatu "era baru" yang ditandai dengan adanya pertumbuhan perdagangan internasional yang tinggi. $^{3}$

Perdagangan bebas mempunyai arti khusus ketika perdagangan diartikan sebagai proses tukar menukar yang didasarkan atas kehendak sukarela dari masing-masing pihak tanpa dibatasi ruang dan waktu. Aspek tanpa dibatas ruang dan waktu menjadi penting dalam perdagangan bebas karena akibat dari globalisasi perdagangan dunia yang terjadi. Sehingga bisa dikatakan, perdagangan bebas muncul karena melihat adanya manfaat dari pengembangan arus tekhnologi.

Perkembangan yang pesat dari teknologi telekomunikasi dan teknologi komputer menghasilkan internet yang multifungsi. Perkembangan ini membawa kita ke ambang revolusi keempat dalam sejarah pemikiran manusia bila ditinjau dari konstruksi pengetahuan umat manusia yang dicirikan dengan cara berfikir yang tanpa batas (borderless way of thinking). Percepatan teknologi semakin lama semakin meningkat yang menjadi sebab material perubahan yang terus menerus dalam semua interaksi dan aktivitas masyarakat informasi.

2 Ibid

3 Bismar Nasution, 2009, Hukum Kegiatan Ekonomi I, Books Terrace \& Library, Bandung, hlm.1.
Kemajuan teknologi telah membawa perubahan dan pergeseran yang cepat dalam suatu kehidupan tanpa batas. Pemanfaatan teknologi tersebut telah mendorong pertumbuhan bisnis yang pesat, karena berbagai informasi dapat disajikan melalui hubungan jarak jauh dan mereka yang ingin mengadakan transaksi tidak harus bertemu muka, akan tetapi cukup melalui peralatan komputer dan telekomunikasi. Teknologi informasi dan komunikasi saat ini sedang mengarah kepada konvergensi yang memudahkan kegiatan manusia sebagai pencipta, pengembang dan pengguna teknologi itu sendiri. Salah satunya dapat dilihat dari perkembangan media internet yang sangat pesat. Internet sebagai suatu media informasi dan komunikasi elektronik telah banyak dimanfaatkan untuk berbagai kegiatan, antara lain untuk menjelajah (browsing, surfing), mencari data dan berita, saling mengirim pesan melalui email, dan perdagangan. Kegiatan perdagangan dengan memanfaatkan media internet ini dikenal dengan istilah electronic commerce, atau disingkat E-Commerce.

Secara singkat E-Commerce dapat dipahami sebagai jenis transaksi perdagangan baik barang maupun jasa lewat media elektronik. Dalam usaha bidang operasionalnya E-Commerce ini dapat berbentuk B to B (Business to Business/ Bisnis untuk Bisnis) atau B to C (Business to Consumers/Bisnis untuk Konsumen). Khusus untuk $B$ to $C$ pada umumnya posisi konsumen tidak sekuat perusahaan sehingga dapat menimbulkan beberapa persoalan. Oleh karena itu para konsumen harus berhati-hati dalam melakukan transaksi lewat internet. Persoalan tersebut antara lain menyangkut masalah mekanisme pembayaran (payment mechanism) dan jaminan keamanan dalam bertransaksi (security risk).

Berdasarkan ketentuan Pasal 1 angka 10 Undang-Undang Nomor 11 Tahun 2008 Tentang Informasi dan Transaksi Elektronik, disebutkan bahwa transaksi elektronik adalah perbuatan hukum yang dilakukan dengan menggunakan komputer, jaringan komputer atau media elektronik lainnya. Transaksi jual beli secara elektronik merupakan salah satu perwujudan ketentuan di atas. Pada transaksi jual beli secara elektronik ini, para pihak yang 
terkait didalamnya, melakukan hubungan hukum yang dituangkan melalui suatu bentuk perjanjian atau kontrak yang juga dilakukan secara elektronik dan sesuai ketentuan Pasal 1 angka 18 Undang-Undang Tentang Informasi dan Transaksi Elektronik (ITE), disebut sebagai kontrak elektronik yakni perjanjian yang dimuat dalam dokumen elektronik atau media elektronik lainnya, hal ini termasuk juga e-mail yang digunakan sebagai "pemberitahuan tertulis" dalam transaksi elektronik.

Dengan demikian semua transaksi jual beli melalui internet ini dilakukan tanpa ada tatap muka antara para pihaknya, mereka mendasarkan transaksi jual beli tersebut atas rasa kepercayaan satu sama lain, sehingga perjanjian jual beli yang terjadi diantara para pihak pun dilakukan secara elektronik pula baik melalui e-mail atau cara lainnya, oleh karena itu tidak ada berkas perjanjian seperti pada transaksi jual beli konvensional. Kondisi seperti itu tentu saja dapat menimbulkan berbagai akibat hukum dengan segala konsekuensinya, antara lain apabila muncul suatu perbuatan yang melawan hukum dari salah satu pihak dalam sebuah transaksi jual beli secara elektronik ini, akan menyulitkan pihak yang dirugikan untuk menuntut segala kerugian yang timbul dan disebabkan perbuatan melawan hukum itu, karena memang dari awal hubungan hukum antara kedua pihak termaksud tidak secara langsung berhadapan, mungkin saja pihak yang telah melakukan perbuatan melawan hukum tadi berada di sebuah negara yang sangat jauh sehingga untuk melakukan tuntutan terhadapanya pun sangat sulit dilakukan tidak seperti tuntutan yang dapat dilakukan dalam hubungan hukum konvensional/biasa. Kenyataan seperti ini merupakan hal-hal yang harus mendapat perhatian dan pemikiran untuk dicarikan solusinya, karena transaksi jual beli yang dilakukan melalui internet tidak mungkin terhenti, bahkan setiap hari selalu ditemukan teknologi terbaru dalam dunia internet, sementara perlindungan dan kepastian hukum bagi para pengguna internet tersebut tidak mencukupi, dengan demikian harus diupayakan untuk tetap mencapai keseimbangan hukum dalam kondisi termaksud.
Pemanfaatan media E-Commerce dalam dunia perdagangan sangat membawa dampak pada masyarakat internasional pada umumnya dan masyarakat Indonesia pada khususnya. Bagi masyarakat Indonesia hal ini terkait masalah hukum yang sangat penting. Pentingnya permasalahan hukum di bidang E-Commerce adalah terutama dalam memberikan perlindungan terhadap para pihak yang melakukan transaksi melalui internet. Mengingat pentingnya hal tersebut maka Indonesia pada tahun 2008 lalu mengeluarkan peraturan khusus yang mengatur transaksi melalui internet yaitu Undang-Undang Nomor 11 tahun 2008 tentang Informasi dan Transaksi Elektronik yang untuk selanjutnya disingkat UU ITE.

Dari uraian di atas, penulis tertarik merumuskan permasalahan tentang :

1. Bagaimanakah Perlindungan Hukum Bagi Para Pihak Dalam E-Commerce sebagai akibat dari globalisasi ekonomi?

2. Bagaimana pengaturan hukum E-Commerce berdasarkan UndangUndang Nomor 11 Tahun 2008?

\section{B. METODE PENELITIAN}

Metode Penelitian yang digunakan adalah yuridis normatif. penelitian hukum kepustakaan adalah penelitian hukum yang dilakukan dengan cara meneliti bahan pustaka atau data sekunder, kemudian untuk diterapkan pada masalah penelitian yakni Perlindungan Hukum Bagi Para Pihak Dalam E-Commerce sebagai akibat dari globalisasi ekonomi sehingga penyajiannya berpangkal pada asas-asas dan teori-teori dan doktrin serta perundang-Undangan yang berlaku. ${ }^{4}$

Spesifikasi penelitian ini adalah bersifat deskriptif sesuai dengan masalah dan tujuan dalam penelitian. Penelitian ini menggambarkan sejumlah variabel yang berkenaan dengan masalah yang diteliti. Dengan kata lain penelitian ini hanya terbatas pada penggambaran satu atau lebih mengenai Perlindungan Hukum Bagi Para Pihak Dalam E-Commerce sebagai akibat dari globalisasi ekonomi.

4 Salim HS dan Erlies Septiana Nurbani, 2013, Penerapan Teori Hukum pada Penelitian Tesis dan Disertasi, Raja Grafindo Persada, Jakarta, hlm.12. 
C. HASIL PENELITIAN DAN PEMBAHASAN

1. Perlindungan Hukum Bagi Para Pihak Dalam E-Commerce sebagai akibat dari globalisasi ekonomi.

Globalisasi bagi bangsa Indonesia dimana masyarakatnya memiliki multi etnis dengan multi budaya melahirkan beberapa tantangan yang tidak ringan yang bisa mengancam keutuhan bangsa dan Negara Indonesia. Tantangan pertama berupa tekanan-tekanan yang datang dari luar baik dalam wujud ekonomi, politik maupun budaya. Ketergantungan atas kekuatan ekonomi internasional menyebabkan bangsa Indonesia tidak dapat melepaskan dari kekuatan tersebut, meski pada kenyataannya hasil yang diperoleh bangsa Indonesia dari ketergantungan tersebut tidaklah selalu manis.

Salah satu wujud dari akibat Globalisasi perdagangan bebas adalah munculnya fenomena Electronic Commerce atau disingkat E-Commerce adalah kegiatan bisnis yang menyangkut konsumen (consumers), manufaktur (manufactures), service providers, dan pedagang perantara (Intermediaries) dengan mengunakan jaringanjaringan komputer (computer networks), yaitu Internet. E-Commerce sudah meliputi seluruh spektrum kegiatan komersial.

Dengan kemudahan berkomunikasi secara elektronik, maka perdagangan pada saat ini sudah mulai merambat ke dunia elektronik. Transaksi dapat dilakukan dengan kemudahan teknologi informasi, tanpa adanya halangan jarak. Julian Ding dalam bukunya E-Commerce: Law \& Practice, mengemukakan bahwa E-Commerce sebagai suatu konsep tidak didefinisikan. E-Commerce memiliki arti yang berbeda bagi orang yang berbeda. Hal itu seperti kita mendefinisikan seekor gajah, yaitu tergantung dari di bagian mana dari gajah itu kita lihat atau pegang, maka akan berbeda pula definisi yang dapat diberikan. ${ }^{5}$ Julian Ding memberikan

5 Julian Ding, 1999, E-Commerce: Law \& Practice.: Sweet \& Maxwell Asia, Malaysia, hlm 25. definisi tentang E-Commerce sebagai berikut :

Electronic Commerce, or E-Commerce as it is also known, is a commercial transaction between a vendor and a purchaser or parties in similar contractual relationships for the supply of goods, services or the acquisition of "rights". This commercial transaction is executed or entered into in an electronic medium (or digital medium) where the physical presence of the parties is not required, and the medium exist in a public network or system as opposed to a private network (closed system). The public network or system must be considered an open system (e.g. the Internet or the World Wide Web). The transactions are concluded regardless of national boundaries or local requirements. ${ }^{6}$

E-Commerce merupakan suatu bidang yang multidisipliner (multidisciplinary field) yang mencakup bidang-bidang teknik seperti jaringan dan telekomunikasi, pengamanan, penyimpanan dan pengambilan data (retrieval) dari multi media; bidang-bidang bisnis seperti pemasaran (marketing), pembelian dan penjualan (procurement and purchasing), penagihan dan pembayaran (billing and payment), dan manajemen jaringan distribusi (supply chain management); dan aspek-aspek hukum seperti information privacy, hak milik intelektual (intellectual property), perpajakan (taxation), pembuatan perjanjian dan penyelesaian hukum lainnya. ${ }^{7}$

Perlindungan hukum dalam hal perjanjian, alat bukti elektronik, dan tanggung jawab para pihak berdasarkan penelitian penulis :

1. Perjanjian

a. Perlindungan hukum di dalam perjanjian E-Commerce.

6 Ibid.

7 Sutan Remy Sjahdeny, E-Commerce Dari Perspektif Hukum, Jurnal Hukum Bisnis,Vol.12,2001, hlm.6. 
Dalam perjanjian terdapat dokumen elektronik, biasanya dokumen tersebut dibuat oleh pihak merchant yang berisi aturan dan kondisi yang harus dipatuhi oleh customer tetapi isinya tidak memberatkan customer. Aturan dan kondisi tersebut juga dipakai sebagai perlindungan hukum bagi kedua belah pihak.

Perlindungan hukum bagi kedua belah pihak adalah :

1) Perlindungan hukum untuk merchant terutama ditekankan dalam hal pembayaran, merchant mengharuskan customer untuk melakukan pelunasan pembayaran dan kemudian melakukan konfirmasi pembayaran, baru setelah itu akan dilakukan pengiriman barang yang dipesan.

2) Perlindungan hukum untuk customer terletak pada garansi berupa pengembalian atau penukaran barang jika barang yang diterima tidak sesuai dengan yang dipesan.

3) Privacy

Data pribadi pengguna media elektronik harus dilindungi secara hukum. Pemberian informasinya harus disertai oleh persetujuan dari pemilik data pribadi. Hal ini merupakan bentuk perlindungan hukum bagi para pihak yang melakukan transaksi E-Commerce, yang termuat dalam Pasal $25 \mathrm{UU}$ ITE "Informasi elektronik dan/ atau dokumen elektronik yang disusun menjadi karya intelektual, situs internet, dan karya intelektual yang ada di dalamnya dilindungi sebagai hak kekayaan intelektual berdasarkan ketentuan peraturan perundangundangan".

b. Perlindungan hukum di luar perjanjian

Hak Atas Kekayaan Intelektual

Perlindungan hukum untuk merchant juga menyangkut tentang Hak Atas Kekayaan Intelektual atas nama domain yang dimilikinya seperti terdapat dalam Pasal 23 UU ITE. Informasi elektronik yang disusun menjadi suatu karya intelektual dalam bentuk apapun harus dilindungi undang-undang yang berkaitan dengan Hak Kekayaan Intelektual. Hal ini disebabkan informasi elektronik memiliki nilai ekonomis bagi pencipta atau perancang. Oleh karena itu, hak-hak mereka harus dapat dilindungi oleh undang-undang HAKI.

Dengan disahkannya Undang-Undang Nomor 8 Tahun 1999 tentang Perlindungan Konsumen pada tanggal 20 April 1999 , telah menjadikan masalah perlindungan konsumen menjadi masalah yang penting, yang artinya kehadiran undang-undang tersebut tidak saja memberikan posisi tawar yang kuat pada konsumen untuk menegakkan hak-haknya, melainkan juga agar dapat tercipta aturan main yang lebih fair bagi semua pihak. Dalam penjelasan UUPK disebutkan bahwa piranti hukum yang melindungi konsumen tidak dimaksudkan untuk mematikan pelaku usaha, tetapi justru sebaliknya, karena perlindungan konsumen akan dapat mendorong iklim berusaha yang sehat serta lahirnya perusahaan yang tangguh dalam menghadapi persaingan melalui penyediaan barang dan/jasa yang berkualitas. 
Dalam kaitannya dengan perkembangan teknologi komunikasi dan informasi di mana barang dan/atau jasa dapat diperdagangkan kepada konsumen melewati batas-batas wilayah, maka perlindungan konsumen akan selalu menjadi isu penting yang menarik untuk diperhatikan.

Konsumen dan pelaku usaha merupakan pihakpihak yang harus mendapat perlindungan hukum. Namun, posisi konsumen pada umumnya lemah dibandingkan dengan pelaku usaha. Hal ini berkaitan dengan tingkat kesadaran akan haknya, kemampuan financial, dan daya tawar (bargaining position) yang rendah. Padahal tata hukum tidak bisa mengandung kesenjangan. Tata hukum harus memposisikan pada tempat yang adil dimana hubungan konsumen dengan pelaku usaha berada pada kedudukan yang saling menghendaki dan mempunyai tingkat ketergantungan yang cukup tinggi satu dengan yang lain.

Posisi konsumen harus dilindungi oleh hukum, karena salah satu sifat dan tujuan hukum adalah memberikan perlindungan (pengayoman) kepada masyarakat. Perlindungan hukum kepada masyarakat tersebut harus diwujudkan dalam bentuk kepastian hukum yang menjadi hak konsumen.

Dalam melakukan transaksi jual beli melalui internet, konsumen juga harus jeli, teliti serta waspada terhadap penawaran yang dilakukan oleh pelaku usaha. Tidak jarang pelaku usaha menawarkan produk yang fiktif, yang dijual murah agar konsumen tertarik. Konsumen harus memastikan dahulu sebelum memesan barang, pastikan merchant mencantumkan nomor telepon yang bisa dihubungi dan alamat lengkapnya. Apabila tertarik dengan barang yang ditawarkannya, maka lakukan komunikasi terlebih dahulu, biasanya pembeli langsung menghubungi lewat telepon, untuk memastikan apakah barang benar-benar ada, setelah itu pembeli baru menanyakan tentang spesifikasi barang yang akan dibelinya. Jika setuju, maka pembeli segera membayar harga atas barang tersebut, kemudian barang dikirimkan. Kegiatan aktif konsumen untuk selalu berkomunikasi atau bertanya tentang barang yang akan dibelinya kepada pelaku usaha akan dapat mengurangi dampak kerugian bagi konsumen.

Dalam rangka mengarahkan aktivitas dan perkembangan dalam Cyberspace, khususnya mendorong dan mengarahkan perkembangan E-Commerce di Indonesia, maka pengaturan khusus dan tegas tentang keabsahan dan kekuatan hukum dokumen elektronik sebagai alat bukti yang sah menjadi hal yang tidak dapat ditawar-tawar lagi.

\section{Pengaturan Hukum E-Commerce} Berdasarkan Undang-Undang Nomor 11 Tahun 2008

Pengaturan hukum berupa peraturan perundang-undangan tentang cyber dan E-Commerce seyogiyanya mencakup perangkat hukum yang berkaitan, sehingga menjadi satu subsistem di dalam sistem hukum nasional. Oleh karena itu, perlu dilakukan perluasan makna dari KUH perdata, Undang-Undang hak cipta, Undang-Undang perlindungan konsumen, Undang-undang Informasi Teknologi 
Elektronik dan Undang-Undang merek terkait dengan hal tersebut. Masalahmasalah legal di internet yang belum terjangkau oleh hukum secara jelas antara lain, kontrak online, Privasi, E-Commerce, pembayaran elektronis, tanggung jawab pembuat hompage, e-mail, dan chat. Dalam hal kontrak dilakukan di cyberspace, peraturan tidak memiliki perbedaan. Namun, bagaimanapun terdapat keadaan di cyberspace yang sama sekali baru dan tidak ada suatu ketentuan pun yang berlaku sehingga menyebabkan ketidakpastian dan resiko bisnis sangat tinggi.

Perubahan drastis dari perilaku komunikasi yang biasanya menggunakan kertas (paper)dankemudianmenggunakan elektronik mengubah sistem kehidupan masyarakat. Gaya hidup yang beralih dari alam wujud (fisik) ke alam elektronik (non fisik) disebutkan sebagai ruang maya (cyberspace). Dalam hukum perdata bisnis, kegiatan di alam maya ini terjadi dalam bentuk kontrak dagang elektronik (E-Commerce). Kontrak dagang tidak lagi merupakan paper-based economy, tetapi digital electronic economy. Pemakaian benda yang tidak berwujud semakin tumbuh dan mungkin secara relatif akan mengalahkan penggunaan benda yang terwujud.

Pengaturan Transaksi E-Commerce dalam Undang-Undang No 11 Tahun 2008 (selanjutnya disebut UU ITE) termasuk gerbang harmonisasi hukum konvensional dan hukum pada era digital, dengan diakuinya e-document sekaligus sebagai perluasan hukum acara yang berlaku di Indonesia (Pasal 5 UU ITE). Akan tetapi diakui bahwa UU ITE masih memerlukan PP turunan sebagai petunjuk pelaksanaan dalam penerjemahan implementasi transaksi elektronik itu sendiri. Pengaturan transaksi E-Commerce dalam UU ITE dapat dijabarkan sebagai berikut.

1. Diperlukannya keberadaan suatu Lembaga Sertifikasi Keandalan untuk melakukan sertifikasi terhadap pihak yang akan melakukan transaksielektronik (Pasal 10);

2. Pengaturan pelaksanaan Transaksi Elektronik (Pasal 17 Ayat (3));

3. Pengaturan mengenai Kontrak Elektronik terhadap Transaksi Elektronik (Pasal 18 Ayat (1));

4. Penyelesaian Sengketa atas Transaksi Elektronik (Pasal 18 Ayat (3));

5. Sistem Elektronik sebagai sistem pelaksanaan Transaksi Elektronik (Pasal 19);

6. Pengaturan mengenai Agen Elektronik sebagai perantara dalam melakukan Transaksi Elektronik (Pasal 21 dan 22); 8

Beberapa pasal hukum yang sudah ada dapat digunakan untuk menyelesaikan hal-hal yang berhubungan dengan masalah cyberspace, sedangkan halhal lainnya harus dituangkan dalam cyberlaw yang baru, sebelum mengarah ke perumusan cyberlaw, harus praktisi di bidang teknologi informasi berharap peraturan mengenai Internet (cyberlaw) tidak dibuat secara khusus, cukup dimasukkan dalam peraturan lain yang terkait.

Arah perkembangan teknologinya belum bisa ditebak dan pasti akan berpengaruh terhadap cara hidup masyarakat, maka sebaiknya tidak perlu diatur secara khusus. Pemerintah perlu mengembangkan struktur regulasi dengan memanfaatkan peraturan perundangan yang telah ada sekarang seperti Undang-Undang Perlindungan Konsumen, Undang-Undang Anti Monopoli, serta pengaturan prdagangan dan investasi. Jadi, tidak perlu dibuatkan aturan khusus dan terpisah, dan semua negara mengalami persoalan yang sama dengan perkembangan internet, sehingga persoalan regulasi $E$-Commerce bukan hanya dihadapi di indonesia saja.

8 http://www.scribd.com/doc/65509415/15/TinjauanTransaksi-E-Commerce-di-Negara-Indonesia diakses pada tanggal 28 Februari 2013 pada pukul 14.00 WIB 
Oleh karena itu, sebaiknya perkembangan teknologi informasi tidak perlu diatur terlebih dahulu sampai ada kejelasan arah perkembangan di bidang teknologi informasi (TI). TI masih akan mengalami perkembangan dengan pesat, sehingga segala kebijakan yang dibuat pemerintah akan terus ketinggalan. Namun, di sisi lain pemerintah perlu memberikan kerangka pendukung seperti iklim investasi yang baik.

Sebagaimana diketahui hukum perjanjian indonesia menyatakan bahwa, suatu perjanjian bersifat onligatoir. Maksudnya adanya kontrak atau lebih tepatnya perikatan baru menimbulkan hak dan kewajiban bagi para pihak yang membuatnya. Hal ini berarti sekalipun sudah ada kontrak jual beli, hak milik atas barang yang diperjualbelikan tadi tidak berpindah sebelum adanya levering atau transfer of title.

Pengaturan hukum berupa peraturan perundang-undangan tentang cyber dan E-Commerce seyogiyanya mencakup perangkat hukum yang berkaitan, sehingga menjadi satu subsistem di dalam sistem hukum nasional. Untuk menggunakan pendekatan sistem sangatlah tepat dengan cara melihat perangkat hukum yang terkait termasuk di dalmnya $\mathrm{KUH}$ Perdata dan perundang-undangan organik lainnya, seperti undang-undang.

\section{PENUTUP}

\section{Kesimpulan}

a. Perlindungan Hukum Bagi Para Pihak Dalam E-Commerce sebagai akibat dari globalisasi ekonomi mencakup 2 (dua) sisi yaitu dalam Perjanjian dan diluar Perjanjian. Perlindungan didalam perjanjian Perlindungan hukum didalam perjanjian E-Commerce, dokumen tersebut dibuat oleh pihak merchant yang berisi aturan dan kondisi yang harus dipatuhi oleh customer tetapi isinya tidak memberatkan customer. Perlindungan hukum diluar perjanjian lebih menyangkut tentang Hak Atas Kekayaan Intelektual atas nama domain yang dimilikinya seperti terdapat dalam Pasal 23 UU ITE.

b. Pengaturan Transaksi E-Commerce dalam Undang-Undang No 11 Tahun 2008 dapat dijabarkan seperti diperlukannya keberadaan suatu Lembaga Sertifikasi Keandalan untuk melakukan sertifikasi terhadap pihak yangakanmelakukantransaksielektronik (Pasal 10); Pengaturan pelaksanaan Transaksi Elektronik (Pasal 17 Ayat (3));Pengaturan mengenai Kontrak Elektronik terhadap Transaksi Elektronik (Pasal 18 Ayat (1)); Penyelesaian Sengketa atas Transaksi Elektronik (Pasal 18 Ayat (3)); Sistem Elektronik sebagai sistem pelaksanaan Transaksi Elektronik (Pasal 19); Pengaturan mengenai Agen Elektronik sebagai perantara dalam melakukan Transaksi Elektronik (Pasal 21 dan 22).

\section{Saran}

a. Diperlukan peran aktif pemerintah untuk segera melihat perkembagangan didalam pengaturan E-Commerce khususnya masalah kontrak, agar dibuat aturan agar setiap kontrak yang ditawarkan didalam situs internet haruslah terlebih dahulu diundangkan didalam Lembaran Negara atau Lembaran Daerah. Disamping itu pemerintah juga harus segera menerima pendaftaran setiap kegiatan usaha di dalam Cyberspace (E-Bussiness) agar pelaku usaha dapat dimonitor, disamping keamanan serta kepastian hukum dalam transaksi E-Commerce supaya dapat berlangsung dengan baik.

b. Bagi parapihakyangtidakmelaksanakan tanggung jawabnya sesuai dengan perjanjian yang telah disepakati bersama, dapat digugat perdata oleh pihak yang dirugikan untuk memperoleh pembayaran ganti rugi sebagaimana disebutkan dalam Pasal 12 UU ITE. 


\section{DAFTAR PUSTAKA}

\section{- Buku-buku :}

Bismar Nasution, 2009, Hukum Kegiatan Ekonomi I, Books Terrace \& Library, Bandung, Fauzie Yusuf Hasibuan, 2010, Keseimbangan Dan Keterbukaan: Dalam Kontrak Anjak Piutang di Indonesia, Fauzie \& Partners, Jakarta.

Julian Ding, 1999, E-Commerce: Law \& Practice.: Sweet \& Maxwell Asia, Malaysia.

Salim HS dan Erlies Septiana Nurbani, 2013, Penerapan Teori Hukum pada Penelitian Tesis dan Disertasi, Raja Grafindo Persada, Jakarta

Sutan Remy Sjahdeny, E-Commerce Dari Perspektif Hukum, Jurnal Hukum Bisnis,Vol.12,2001.

\section{- Website :}

http://www.scribd.com/doc/65509415/15/Tinjauan-Transaksi-E-Commerce-di-Negara-Indonesia 